\title{
The Impact of Salesperson's Personality to Job Performance in Machinery Industry in Viet Nam
}

\author{
Tam Luong HUYNH ${ }^{1}$, Ha Minh NGUYEN ${ }^{2}$, Tram Thi Bich KIEU ${ }^{3}$
}

Received: July 25, 2020 Revised: August 23, 2020 Accepted: September 03, 2020

\begin{abstract}
This research focuses on identifying and measuring key personality factors affecting the job performance of salesperson working in the machinery industry in Vietnam. A total number of 218 salesperson working in machinery industry were surveyed. After evaluating Cronbach's Alpha and using the regression analysis technique, the results show the impact level of personality trait factors affecting the job performance of salesperson working in machinery industry. Ordered from the highest to the lowest effects on job performance, these factors are: agreeableness, openness to experience, conscientiousness, extraversion, and neuroticism. Five research hypotheses are accepted. Specifically, openness to experience, conscientiousness, extraversion, and agreeableness have positive impacts on job performance of salesperson working in machinery industry in Vietnam. However, neuroticism has a negative impact on job performance of salesperson. This research results indicate the level of impact of personality traits on the sales staff performance in machinery industry. Many people apply to this profession as a career choice. Each occupation is suitable for certain personality trait, which changes very little during adulthood. Research also shows that each personality trait always has its strengths and weaknesses. The educational environment should create conditions for learners to develop their character in a natural way.
\end{abstract}

Keywords: Personality, Personality Trait, Job Performance, Salesperson, Machinery Industry

JEL Classification Code: L64, L16, M12, M54

\section{Introduction}

Machinery is one of the resources that support people as they participate directly in the production process, especially in the Industry 4.0 era, which is creating opportunities for the machinery industry to develop. In order to deal with the stiff competition of the market, in addition to constantly update new technologies and research appropriate supply chains, managers in the industry also need to invest in developing human resources, especially sales staff. However, the reality is that more and more people want to become salesperson, although they do not realize whether they are suited to the

${ }^{1}$ First Author and Corresponding Author. PhD Student, Ho Chi Minh City Open University, Vietnam [Postal Address: 97 Vo Van Tan Street, District 3, Ho Chi Minh City, 700000, Viet Nam] Email: tam.hl@ou.edu.vn

${ }^{2}$ Associate Professor, President, Ho Chi Minh City Open University, Viet Nam. Email: ha.nm@ou.edu.vn

${ }^{3} \mathrm{Ho}$ Chi Minh City Open University, Viet Nam.

Email: tramktb.158b@ou.edu.vn

(c) Copyright: The Author(s)

This is an Open Access article distributed under the terms of the Creative Commons Attribution Non-Commercial License (https://creativecommons.org/licenses/by-nc/4.0/) which permits unrestricted non-commercial use, distribution, and reproduction in any medium, provided the original work is properly cited. job. It seems that managers still do not really care about this issue.

In the past, researchers with a variety of points of view have discovered many different factors influencing sales results. Some managers consider a sale job, a job that can be learned and trained for. Previous studies showed that the factors that affect the performance of salesperson are perceptions about business, products, skills, and ability (Boles et al, 2000; Brashear et al, 1997; Cross et al, 2007); individual market orientation (Smith \& Tennessee, 2010; Han, 2020); customer orientation (Cross et al, 2007); and sales skills (Basir et al, 2010). While other managers argue that good sales staff need certain qualities.

In fact, managers focus much on professional training for employees, but employees do not necessarily achieved the highest job performance desired by managers. This involves costs, time and effort to train, thereby causing damage to the organization. James et al (2013) concluded that, though trained with the same curriculum and courses such as teamwork, customer service orientation, etc., the employees with different personality trait factors bring different organizational and business success. Therefore, personality trait issues need to be taken seriously in recruitment and work arrangements for employees to help improve work performance, and continually develop the organization. 
There are many studies explaining the influence of personality trait on work-related factors. Rothmann and Coetzer (2003) observed direct a relationship between personality trait and overall job performance. Other studies assess the impact of personality trait on job performance (Furnham \& Fudge, 2008; Hurtz \& Donovan, 2000; Smith $\&$ Tennessee, 2010; Verbeke, 1994; Tran et al., 2020). Most of them use the Big Five Factors Model as ground theories. However, studies lead to different results across different research contexts.

\section{Literature Review}

\subsection{Personality Trait}

Personal psychology is a branch of psychology. It investigates personality differences between individuals, recognizing people as unique, characterized by their own personalities. Bradberry (2007) argued that personality is a psychological difference between individuals, making a unique individual with distinctive psychological characteristics. Carpenter et al (2009) defined personality trait as a sequence of emotions and thoughts. Each individual has a unique personality and that makes himself or herself different from everyone else. According to Golberg (1981), every human being is characterized by trait or characteristics called personality. These characteristics are formed through the process of human perception surrounding environment and themselves. These characteristics are relatively stable, vary between individuals and affect the behavior of those individuals (Han, 2020). Human personality trait is described by five continuous elements, coined OCEAN (Openness to experience, Conscientiousness, Extraversion, Agreeableness, Neuroticism); it is also called Big Five Factors Model. These factors are defined as follows:

Openness to experience is a factor to describe experimenting, appreciating the curiosity, exploring, and investigating new things. Conscientiousness is assessing the level of self-organizing ability, prestige, and motivation in behaviors towards personal goals. Extraversion refers to people who are self-affirmative and prefer newness. They like to seek stimulation, tend to be optimistic and have positive emotions. Agreeableness refers to people who are selfless, sympathetic to others, desire to help others, and believe that others are also helpful people. Neuroticism refers to assessing emotional instability, recognizing individuals who are prone to psychological stress, with unrealistic ideas and outrageous desires.

\subsection{Job Performance of Salesperson}

Job performance is a multidimensional concept, which researchers agree is not easy to conceptualize (Ha et al, 2019).
According to Herzberg (1959), job performance is "giving an employee what I want him to do". Lindner (1998) argues that the performance of an employee can be regarded as "the capital gain from the outside". According to Vroom (1964), job performance is based on many personal factors, namely, personality, skills, knowledge, experience, and ability. According to Jamal (1984), job performance is defined as an activity, in which an individual could successfully complete the assigned task.

However, according to researchers, it is not a matter of defining what job performance is, but how it is fulfilled, and how it is measured (Furnham et al, 1999; Barrick \& Mount, 1991). Wetzels et al. (2000) described job performance as the extent to which employees perform tasks and responsibilities. Suliman (2001) proposed six components: work skills, job task, enthusiasm, quality, quantity of work, and willingness to innovate. According to the Baldrige standard, work results refer to outputs, results obtained from the process and allowed to be compared and evaluated relative to previous goals and results. The most appropriate definition of job performance in this study is: "the effectiveness of an individual's behavior toward the organization's goals based on the quality of the work accomplished". Job performance is based on the judgment of oneself, peers and superiors. Therefore, this study uses Behrman's scale (1982): high sales, quickly selling new products, creating a large market share, find and sell to most important customers, sell products with high profit, and help superiors achieve their goals.

\subsection{Personality Trait and Job Performance of Salesperson}

Rothmann and Coetzer (2003) observed a direct relationship between personality trait and overall performance. Klang (2012) explored the relationship between personality trait and sales performance. Other researchers have assessed the influence of personality trait on sales performance (Furnham \& Fudge, 2008; Hurtz \& Donovan, 2000; Smith \& Tennessee, 2010) and most of them used the Big Five Factors Model of personality trait. Pendhaharkar and Pandey (2011) found that sellers with high confidence and good profiles were more likely to easily generate revenue from new customers. Wisker (2011) also showed the influence of extraversion on sales activities.

\subsubsection{Openness to Experience and Job Performance of Salesperson}

Openness to experience involves curiosity, interest in exploring, intellectual curiosity, and independence of judgment. Previous research showed that openness to experience was linked to successful consultation (Hamilton, 1988; Vinchur et al, 1998) and adapting to change (Raudsepp, 
Tam Luong HUYNH, Ha Minh NGUYEN, Tram Thi Bich KIEU /

Journal of Asian Finance, Economics and Business Vol 7 No 10 (2020) 377-389

1990). The studies by Barrick and Moun (1991); Furnham and Fudge (2008) showed that openness to experience related to training, because individuals who scored high on this trait often had a positive attitude towards learning new experiences, often tended to be positive about their personal ideas and experiences. According to Judge et al (2002), this factor was positively related to the motivation for accomplishing work goals set by individuals. Moreover, an employee's openness to experience often tends to be based on practical tasks, constantly seeking new ways to accomplish his work (Steward \& Nandkeolyar, 2006), thus, achieving results at work. Meanwhile, in contrary, Johnson (1997) found that successful employees (compared to unsuccessful employees) displayed significantly lower openness to experience. Tett et al (1991) reported that the openness to experience was not significant in performance evaluation. Different jobs with different requirements explain the contradictory results regarding the relationship between openness to experience and performance. Therefore, the first hypothesis is proposed as follows:

H1: Openness to experience has a positive effect on job performance of salesperson

\subsubsection{Conscientiousness and Job Performance of Salesperson}

Conscientiousness refers to a sense of responsibility, diligence, trustworthiness and thoughtfulness. A conscientious person is someone who is purposeful, strongwilled and determined. Conscientiousness is expressed in working attitude (work hard and continuity), trust (responsible and careful), and order (planning and organizing). It refers to self-control and operational process of planning, organizing and implementing tasks (Barrick et al., 1991). Conscientious people are usually careful, thorough, responsible, organized and self-disciplined at work (McCrae \& Costa, 1987). Hough et al. (1990) found a correlation between reliability (an aspect of conscientiousness) and performance. Other researchers (Barrick \& Mount, 1991; Barrick \& Ryan, 2004) have found a strong correlation between conscientiousness and job performance. Highly devoted employees tend to believe that their job is of special importance, so they are more engaged with their organization (Li et al., 2007). They also adjust their behaviors more effectively (Wallace \& Chen, 2006). Judge et al. (2002) showed that conscientiousness was instrumental to the employee's success, as well as motivation to move forward and the desire to work more effectively. According to Kumar and Bakhshi (2010), people with a high level of conscientiousness display a strong sense of purposeful work, high responsibility at work, perseverance and a tendency to perfection. In this study, salespersons who value themselves as highly conscientiousness, also receive high ratings in job performance. For that reason, the second hypothesis is proposed as follows:

H2: Conscientiousness has a possitive effect on job performance of salesperson

\subsubsection{Extraversion and Job Performance of Salesperson}

Extraversion includes trait such as sociality, assertiveness, activity, and loquacity. Extroverts are usually active and optimistic, qualified social activities, sociable, like to participate in social activities. They are also self-assertive, seeking stimulation, optimistic tendencies and positive emotions. Extraversion is characterized by positive emotions and experience. Therefore, it is considered a positive impact (Clark \& Watson, 1991). Research by Barrick and Mount (1991) showed that extroverted individuals had the potential to excel in their careers. Johnson (1997) found a positive relationship between extraversion and police officer performance, and explained this relationship by the high level of interaction. In addition, Vinchur et al (1998) conducted an analysis showing that extraversion had a positive relationship with the sales performance of salesperson. Smithikrai (2007) found a positive connection between extrovert and job success, especially in work that requires communication. Van Den Berg and Feij (2003) also suggested that employees with high extrovert score made better use of their capacity compared to low extroverted employee, which in turn leads to better efficiency and performance. It can be seen that extraversion is a predictor of job performance characterized by social interaction, such as salesperson and managers (Barrick \& Mount, 1991; Vinchur et al, 1998).

Based on the previous studies, salesperson who are extroverted are able to perform better in sales, especially because their work often requires requires harmony with customers. So, the third hypothesis is formulated as follow:

H3: Extraversion has a possitive influence on job performance of salesperson

\subsubsection{Agreeableness and Job Performance of Salesperson}

Agreeableness relates to empathy, assistance quality, versatility, flexibility. People who are pleasant, easy to accept others, selfless, easy to empathize with others, desire to help others and believe that others are also helpful. Costa and McCrae (1992) argued that people who were pleasant to trust others, tolerance, softness and compassion. Comfortably individuals lead to career success especially in team workplaces and customer service (Judge et al., 1999). Research by Barrick and Mount (1991) and Tett et al. (1991) 
found a correlation between agreeableness and performance. Thoresen et al. (2004) found a positive relationship between agreeableness and performance. Although other studies, such as those conducted by Witt et al. (2002), argued that sometimes agreeableness could have a strong impact on job performance because it resonates with other personality components such conscientiousness. In addition, Thoresen et al. (2004) also concluded that pleasant salesperson could achieve success in the next stage such as customer development and customer orientation. Matzler et al. (2011) pointed out that pleasant people often put themselves in comfortable relationships and easy to get satisfaction from those around.

In fact, salesperson have to collaborate with different departments and have to meet different kind of customers, so agreeableness plays an important role in the performance of their job. Therefore, this study's fourth hypothesis is proposed as follows:

H4: Agreeableness has a positive influence on job performance of salesperson

\subsubsection{Neuroticism and Job Performance of Salesperson}

Neuroticism is a personality trait aspect that refers to individuals who tend to be ashamed, angry, insecure, depressed, vulnerable, and anxious. (Costa \& McCrae,
1992). This feature focuses on assessing an individual's tendency to experience negative emotional, adjusting and adapting to fear, sadness, anxiety, embarrassment, anger, low self-esteem, guilt and despair. Meanwhile, people with better psychological stability often achieve high results especially in jobs that require emotional and psychological stability like salesperson because they always have to deal with customers, who have different cultural values, beliefs, social orientations, needs and fickle temperament.

The employees with neuroticism often perform poorly at work (Abdullah et al, 2013). Moreover, because employees with high neuroticism often have negative emotions such as anger, anxiety, depression, and vulnerability, they often fail to drive customers or, in other words, this trait is incompatible with the job of salesperson (Arndt \& Karande, 2012). Dunn et al (1995) pointed out that emotional stability was the important characteristic that affects job candidates. Judge et al (1999) found that neuroticism has a negative relationship with job performance. Therefore, the fifth hypothesis is proposed as follows:

H5: Neuroticism has a negative effect on job performance of salesperson

\subsection{Research Model}

Figure 1 displays the conceptual model of this research.

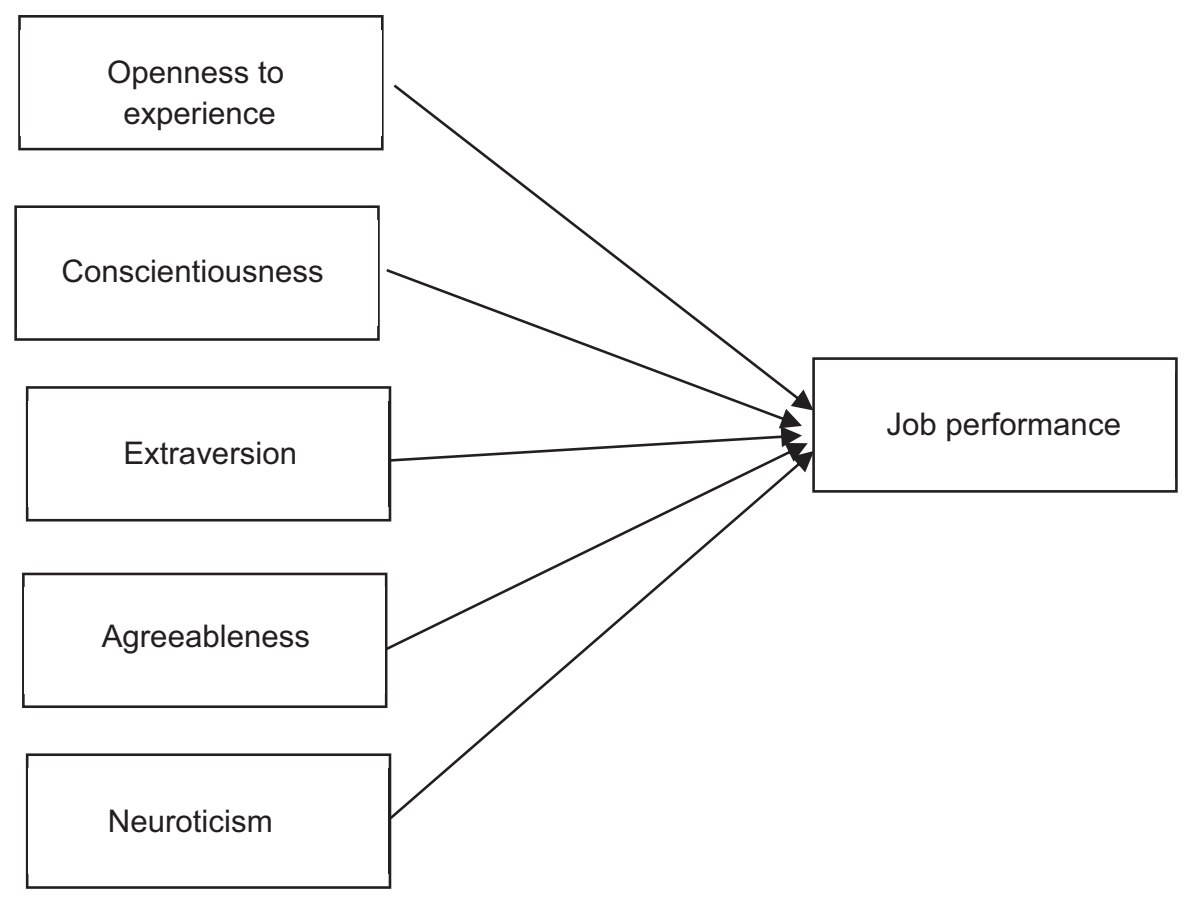

Figure 1: Proposed research model 


\section{Research Methods}

Both qualitative research and quantitative research are used. The data was collected by survey questionnaire.

Qualitative research was conducted via an interview with five salesperson who have over one year working at five major machinery and equipment companies in Ho Chi Minh City, in order to develop and adjust the observed variables. After interviewing two employees, from the 3rd and 4th staff, the ideas started to overlap, no new information was discovered, so we stopped and determined that the sample for qualitative research is four. Research results corrected five observed variables, removed 18 observed variables, added three new observed variables in the "Personality trait" scale. Moreover, the results adjusted two observed variables, combined three observed variables into one observed variables, and added four new observed variables in the scale "Job performance".

Quantitative research involved a survey of 300 sales employees working in machinery and equipment companies in Vietnam. There were 218 valid answers. We used a 5-point Likert scale ,"1-Totally disagree", "2-Disagree",
"3-Neutral", "4-Agree", "5. Totally agree", to measure observed variables in each factor.

\section{Empirical Results}

\subsection{Descriptive Statistics}

Gender: Due to the special characteristics of the machinery and equipment industry, most of the respondents are male, accounting for $74.8 \%$.

Age: There are 47 people under the age of 25, accounting for $21.6 \%$. Respondents from 25 to 30 accounted for the highest proportion of $63.3 \%$, and 33 people over 30 accounted for the lowest proportion of $15.1 \%$.

Monthly income: Most of the respondents earn VND510 million per month, accounting for $54.1 \%$. People with income from VND10-15 million per month accounted for the second highest proportion in the sample, with $28.9 \%$. Finally, the group of respondents with an income of less than VND5 million per month accounted for $11.5 \%$ and only 12 respondents had incomes of over VND15 million per month.

Table 1: Descriptive statistics

\begin{tabular}{|c|c|c|c|}
\hline & & & \\
\hline & & Frequency & Percentage (\%) \\
\hline Condor & Male & 163 & 74.8 \\
\hline Gender & Female & 55 & 25.2 \\
\hline & $<25$ years old & 47 & 21.6 \\
\hline Age & 25 - 30 years old & 138 & 63.3 \\
\hline & $>30$ years old & 33 & 15.1 \\
\hline & $<5$ million VND & 25 & 11.5 \\
\hline Monthlyincomo (VND) & $5-10$ million VND & 118 & 54.1 \\
\hline 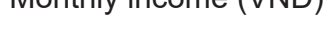 & 10 - 15 million VND & 63 & 28.9 \\
\hline & $>15$ million VND & 12 & 5.5 \\
\hline & College & 41 & 18.8 \\
\hline Education & University & 162 & 74.3 \\
\hline & Postgraduate & 15 & 6.9 \\
\hline & $<1$ year & 32 & 14.7 \\
\hline Eynorionse & $1-5$ years & 105 & 48.2 \\
\hline Ехрепепісе & $5-10$ years & 64 & 29.4 \\
\hline & $>10$ years & 17 & 7.8 \\
\hline & Salesperson & 170 & 78.0 \\
\hline Ioh nocition & Sale leader & 32 & 14.7 \\
\hline 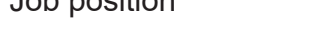 & Sale manager & 14 & 6.4 \\
\hline & Others & 2 & 0.9 \\
\hline
\end{tabular}


Education: The majority of respondents graduated from university, accounting for $74.3 \%$. After that, the group with college qualifications accounted for $18.8 \%$ and postgraduate level accounted for $6.9 \%$.

Experience: Respondents who worked less than one year with the company accounted for $14.7 \%$. The highest proportion is the group of respondents who have 1-to-5 years working experience, accounting for $48.2 \%$. Meanwhile, respondents with more than 10 years' experience, accounted for the lowest percentage of $7.8 \%$. The respondents who have worked for 5 to 10 years accounted for $29.4 \%$.

Job position: Survey respondents mainly focused on sales staff, accounting for $78.0 \%$ followed by sales leader group, with $14.7 \%$. Sales manager group accounted for $6.4 \%$ and the others $0.9 \%$ (see Table 1 ).

\subsection{Descriptive Statistics of Observed Variables}

Neuroticism: According to the analysis results, the survey participants have little psychological instability when the mean value of this component is quite low. The observed variables $\mathrm{N} 1, \mathrm{~N} 2, \mathrm{~N} 5$ have the highest and approximate values from 2.46 to 2.48 , indicating that respondents encountered depression, sadness, nervousness and led to mental stress.

Extraversion: The sales staff in the machinery and equipment industry is extroverted with the mean value of the observed variables ranging from 2.94 to 3.73 . They always feel energetic, enthusiastic at work, but a bit lacking in assertiveness.

Openness to experience: The sales staff in the machinery and equipment industry in Vietnam prefers to experience new things, with the mean value of observed variables being approximately the same and higher than the average (3.00 to 3.11). They are very supportive of breaking into new ways while doing work and do not like repetitive, boring job.

Agreeableness: Respondents are the type who are quite comfortable in life and work (mean value of the observed variables from 3.13 to 3.59). In particular, they tend to prefer cooperation and working with many different people, but may not be ready to always be tolerant and forgive mistakes. (A4 reaches the maximum value of 3.59 and A2 reaches the lowest value of 3.13).

Conscientioiusness: The sales staff in the machinery and equipment industry is dedicated and wholeheartedly at work. They know how to formulate and adhere to their own plans to achieve individual and collective goals. They feel like they are trustworthy at work and know how to work effectively. However, some people still do not have the patience to pursue the final goal (the mean value of $\mathrm{C} 3$ is smallest with 3.29).

Job performance: The sales staff, who participated in the survey, focuses on achieving high sales and profits and are concerned about solving customer problems (variables JP1 and JP5 reached the highest mean values of 3.22 and 3.23 ). However, the ability to learn and sell new products needs to be improved (mean value of JP3 is at least with 3.00) (see Table 2).

\subsection{Reliability of Scale and Exploratory Factor Analysis (EFA)}

\subsubsection{Reliability of Scale}

The indicators E4, O4, C3, and JP1 were disqualified because of corrected item-total correlation less than 0.3 when performing Cronbach's Alpha testing. After that, Cronbach's Alpha coefficients of all factors range from 0.843 to 0.941 , which are all more than 0.7 ; all of the observed variables measuring these factors achieve a total correlation coefficient of variables above 0.3 . Therefore, those remaining observed variables measuring the above factors, as shown in Table 3, are all qualified to be added into EFA.

\subsubsection{Exploratory Factor Analysis (EFA)}

All observed variables belong to personality traits' scale (26 indicators), which were analyzed with Varimax rotation. The results of EFA were qualified with $\mathrm{KMO}=$ 0.828 , Bartlett's test sig. $=0.000$, total Eigenvalue $=1.841$, $\%$ Cumulative $=69.628 \%$. All 26 indicators were extracted into five groups of factors, unchanged from the original (see Table 4). Then, this study performed EFA in turn for indicators belonging to scale "job performance". The results showed that one component was extracted with $\mathrm{KMO}=$ 0.877 , Bartlett's test sig. $=0.000$, total Eigenvalue $=5.827$, $\%$ Cumulative $=72.839 \%$.

\subsection{Regression Analysis}

After conducted EFA, all indicators are retained for linear regression analysis. The results showed that with adjusted $\mathrm{R}^{2}=0.565$, this mean $56.5 \%$ of "Job performance" can be explained by five components of "Personality trait". In F-testing, sig. $=0.000$, so this model is suitable with the data. The maximum VIF value was 1.360 , so there were no autocorrelation and multicollinearity happening (see Table 5).

Openness to experience has a positive effect on job performance (H1): The factor "Openness to experience " with sig. $=0.000$, is significant at the $1 \%$ level and $\beta 1=$ $0.237>0$, so hypothesis H1 is accepted. This result reflects that the employees of the machinery and equipment industry who prefer to be willing to experience are likely to have better job results. Salesperson should consult products for customer with openness and willingness to experience with 
Table 2: Descriptive statistics of observed variables

\begin{tabular}{|c|c|c|c|}
\hline Items & Content & Source & Mean \\
\hline & Neuroticism & & \\
\hline N1 & Often depressed, sad & \multirow{7}{*}{ John \& Srivastava (1999) } & 2.46 \\
\hline N2 & Prone to stress & & 2.48 \\
\hline N3 & Worry about things & & 2.43 \\
\hline N4 & Mood swings & & 2.26 \\
\hline N5 & Ease suspense & & 2.46 \\
\hline N6 & Easy to get down mentally & & 2.38 \\
\hline \multirow[t]{2}{*}{ N7 } & Difficult to keep calm in difficult situations & & 2.31 \\
\hline & Extraversion & & \\
\hline E1 & Talkative & \multirow{4}{*}{ John \& Srivastava (1999) } & 3.39 \\
\hline E2 & Vivacious, always energetic & & 3.73 \\
\hline E3 & Very enthusiastic & & 3.70 \\
\hline E4 & Accurate and assertive & & 2.94 \\
\hline E5 & Like to communicate & \multirow{2}{*}{ Qualitative research } & 3.33 \\
\hline \multirow[t]{2}{*}{ E6 } & Enjoy doing work going outside & & 3.51 \\
\hline & Openness to experience & & \\
\hline O1 & Often have new ideas & \multirow{6}{*}{ John \& Srivastava (1999) } & 3.03 \\
\hline $\mathrm{O} 2$ & Curious with new things & & 3.06 \\
\hline $\mathrm{O} 3$ & Thinking deeply and think about the issues in depth & & 3.16 \\
\hline $\mathrm{O} 4$ & Rich imagination & & 3.08 \\
\hline O5 & Creativity & & 3.09 \\
\hline 06 & Dislike the job to work as prescribed and repetitive work & & 3.11 \\
\hline \multirow[t]{2}{*}{$\mathrm{O} 7$} & Curious with many things & Qualitative research & 3.00 \\
\hline & Agreeableness & & \\
\hline A1 & Regularly help and share with people & \multirow{4}{*}{ John \& Srivastava (1999) } & 3.32 \\
\hline A2 & As tolerant, easy to forgive & & 3.13 \\
\hline A3 & Flexible, adaptable in many different situations & & 3.20 \\
\hline \multirow[t]{2}{*}{ A4 } & Ease of cooperation with different people & & 3.59 \\
\hline & Conscientioiusness & & \\
\hline $\mathrm{C} 1$ & Work carefully & \multirow{5}{*}{ John \& Srivastava (1999) } & 3.56 \\
\hline $\mathrm{C} 2$ & Reliable people at work & & 3.65 \\
\hline C3 & Try your best to get the job done & & 3.29 \\
\hline $\mathrm{C} 4$ & Do things efficiently & & 3.57 \\
\hline \multirow[t]{2}{*}{$\mathrm{C5}$} & Planning and following the plan & & 3.98 \\
\hline & Job performance & & \\
\hline JP1 & $\begin{array}{l}\text { You sell products with the highest gross profit. (Gross profit }= \\
\text { (price }- \text { cost) } x \text { quantity) }\end{array}$ & \multirow{4}{*}{ Behrman \& Perreault (1982) } & 3.22 \\
\hline JP2 & You achieve the target sales & & 3.10 \\
\hline JP3 & You sell new products very quickly. & & 3.00 \\
\hline JP4 & You always follow company policies and procedures & & 3.15 \\
\hline JP5 & You deal well with customer complaints & \multirow{2}{*}{ Qualitative research } & 3.23 \\
\hline JP6 & Customers are satisfied with your service attitude. & & 3.03 \\
\hline JP7 & You know very well about your company's products & Behrman \& Perreault (1982) & 3.18 \\
\hline JP8 & You know very well about your opponent's product. & \multirow{2}{*}{ Qualitative research } & 3.09 \\
\hline JP9 & You know very well about customer needs. & & 3.09 \\
\hline
\end{tabular}


Table 3: Cronbach's Alpha coefficients

\begin{tabular}{|c|c|c|c|}
\hline Observed Variables & $\begin{array}{c}\text { Cronbach's Alpha if Item } \\
\text { Deleted }\end{array}$ & $\begin{array}{c}\text { Corrected Item-Total } \\
\text { Correlation }\end{array}$ & $\begin{array}{c}\text { Cronbach's Alpha if Item } \\
\text { Deleted }\end{array}$ \\
\hline \multicolumn{4}{|c|}{ Neuroticism $($ Cronbach's Alpha $=0.910)$} \\
\hline N1 & 14.32 & 0.712 & 0.899 \\
\hline N2 & 14.30 & 0.710 & 0.899 \\
\hline N3 & 14.35 & 0.661 & 0.904 \\
\hline N4 & 14.52 & 0.662 & 0.904 \\
\hline N5 & 14.31 & 0.797 & 0.890 \\
\hline N6 & 14.39 & 0.775 & 0.892 \\
\hline N7 & 14.46 & 0.791 & 0.890 \\
\hline \multicolumn{4}{|c|}{ Extraversion (Cronbach's Alpha $=0.883)$} \\
\hline E1 & 14.26 & 0.639 & 0.877 \\
\hline E2 & 13.92 & 0.779 & 0.844 \\
\hline E3 & 13.95 & 0.754 & 0.852 \\
\hline E5 & 14.33 & 0.654 & 0.874 \\
\hline E6 & 14.14 & 0.785 & 0.842 \\
\hline \multicolumn{4}{|c|}{ Openness to experience (Cronbach's Alpha $=0.889$ ) } \\
\hline 01 & 15.42 & 0.803 & 0.856 \\
\hline $\mathrm{O} 2$ & 15.39 & 0.702 & 0.871 \\
\hline O3 & 15.29 & 0.609 & 0.887 \\
\hline O5 & 15.36 & 0.657 & 0.878 \\
\hline O6 & 15.33 & 0.761 & 0.862 \\
\hline 07 & 15.45 & 0.730 & 0.867 \\
\hline \multicolumn{4}{|c|}{ Agreeableness (Cronbach's Alpha $=0.892)$} \\
\hline A1 & 9.92 & 0.860 & 0.822 \\
\hline A2 & 10.11 & 0.740 & 0.869 \\
\hline A3 & 10.04 & 0.794 & 0.852 \\
\hline A4 & 9.64 & 0.667 & 0.897 \\
\hline \multicolumn{4}{|c|}{ Conscientiousness (Cronbach's Alpha $=0.843$ ) } \\
\hline C1 & 11.21 & 0.704 & 0.792 \\
\hline $\mathrm{C} 2$ & 11.12 & 0.711 & 0.786 \\
\hline C4 & 11.20 & 0.636 & 0.819 \\
\hline $\mathrm{C5}$ & 10.79 & 0.667 & 0.807 \\
\hline \multicolumn{4}{|c|}{ Job performance (Cronbach's Alpha $=0.941)$} \\
\hline JP2 & 21.77 & 0.907 & 0.926 \\
\hline JP3 & 21.88 & 0.845 & 0.930 \\
\hline JP4 & 21.72 & 0.898 & 0.926 \\
\hline JP5 & 21.64 & 0.475 & 0.955 \\
\hline JP6 & 21.84 & 0.755 & 0.936 \\
\hline JP7 & 21.69 & 0.703 & 0.940 \\
\hline JP8 & 21.78 & 0.883 & 0.927 \\
\hline JP9 & 21.78 & 0.896 & 0.927 \\
\hline
\end{tabular}


Table 4: Results of exploratory factor analysis

\begin{tabular}{|c|c|c|c|c|c|}
\hline & \multicolumn{5}{|c|}{ Component } \\
\hline & 1 & 2 & 3 & 4 & 5 \\
\hline N7 & 0.848 & & & & \\
\hline N6 & 0.840 & & & & \\
\hline N5 & 0.832 & & & & \\
\hline N1 & 0.805 & & & & \\
\hline N2 & 0.798 & & & & \\
\hline N3 & 0.697 & & & & \\
\hline N4 & 0.691 & & & & \\
\hline 01 & & 0.864 & & & \\
\hline 06 & & 0.846 & & & \\
\hline $\mathrm{O} 2$ & & 0.823 & & & \\
\hline $\mathrm{O} 7$ & & 0.761 & & & \\
\hline O5 & & 0.734 & & & \\
\hline $\mathrm{O} 3$ & & 0.687 & & & \\
\hline E6 & & & 0.869 & & \\
\hline E2 & & & 0.840 & & \\
\hline E3 & & & 0.797 & & \\
\hline E5 & & & 0.777 & & \\
\hline E1 & & & 0.742 & & \\
\hline A1 & & & & 0.900 & \\
\hline A3 & & & & 0.834 & \\
\hline A2 & & & & 0.799 & \\
\hline A4 & & & & 0.746 & \\
\hline $\mathrm{C} 2$ & & & & & 0.834 \\
\hline C1 & & & & & 0.819 \\
\hline C4 & & & & & 0.796 \\
\hline C5 & & & & & 0.788 \\
\hline
\end{tabular}

Table 5: Regression results

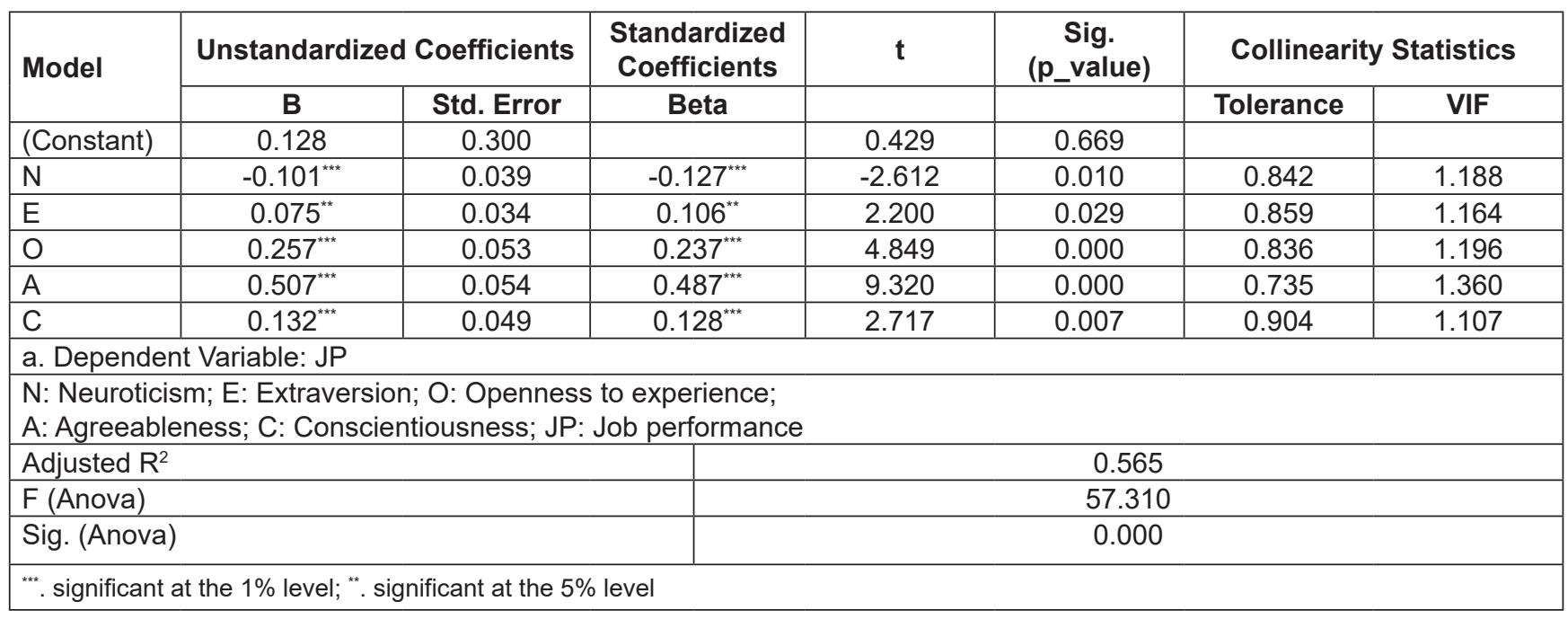


new challenges from many different customers that will help them be more successful in counseling (Hamilton, 1988), and adapting to change (Raudsepp, 1990; Ha \& Nguyen, 2014). In addition, with openness to experience, salesperson in the machinery and equipment industry will be ready to take on the challenges of developing agents, distribution markets, and proposing and implementing business plans to achieve targeted sales.

Conscientiousness has a possitive effect on job performance (H2): The factor "Conscientiousness" has a significant level at $1 \%(\mathrm{sig}=0.007)$ and $\beta 2=0.128>0$, indicating that hypothesis $\mathrm{H} 2$ is accepted. This result shows that, if the sales staff is more dedicated to work, it will have a better job performance. Employees with a high character in this component are people with a strong sense of purpose and determination. Conscientiousness is reflected in achievement orientation (hard and repeatedly), reliability (responsible and careful) and order (which planned and organized), so, dedicated employees will get ranked and appreciated when making work. This result is consistent with previous studies by Barrick and Mount (1991); Barrick et al (1993), Nguyen et al. (2019); Hough et al. (1990) who also found a positive correlation between reliability (an aspect of conscientiousness) and job performance.

Extraversion has a possitive influence on job performance (H3): The factor "Extraversion" with sig. $=0.029$ is significant at the $5 \%$ level and $\beta 3=0.106>$ 0 . Therefore, hypothesis $\mathrm{H} 3$ is accepted. If the salespersons in machinery and equipment industry are more extroverted, then their job performance may be better. It can be seen that salespersons in machinery and equipment industry are extroverted, not introverted people, able to perform better in sales, especially as this job often requires an ability to get along with customers, to maintain business relationships with existing customers as well as developing new customers. This result is quite similar to studies by Barrick and Mount, 1991; Johnson (1997); Vinchur et al (1998); Ha and An (2015).

Agreeableness has a possitive influence on job performance (H4): The factor "Agreeableness" with sig. $=0.000$, is significant at the $1 \%$ level and $\beta 4=0.487>0$, thus hypothesis $\mathrm{H} 4$ is accepted. It means that, when sales staff tends to display agreeableness as a personality trait, it is more likely to achieve a better job performance. In fact, sales staff must collaborate with other people from many departments as well as many customers with different personalities and requirements. Given the nature of the cooperation, pleasant staff can have a successful career, where teamwork and customer service are related. This result is fully consistent with earlier studies by Barrick and Mount (1991); Tett et al (1991); Judge et al (1999); Nguyen, Mai, Huynh (2019) and Salgado (1997).

Neuroticism has a negative effect on job performance (H5): The factor "Neuroticism" is significant at the 1\% level (sig. $=0.010)$ and $\beta 5=-0.127<0$, indicating that hypothesis $\mathrm{H} 5$ is accepted. This result shows that sales staff in machinery and equipment industry that has psychological instability will not have a high job performance. Sales staff with high level of neuroticism easily has unreasonable thoughts and is less able to control impulses, as well as the ability to control low tension resulting in low performance. Dunn et al (1995) pointed out that psychological stability is the second most important characteristic that affects job performance.

\section{Conclusions and Managerial Implications}

\subsection{Conclusions}

This study uses the Big Five Model and Mini Test with 44 questions that measure personality trait characteristics inherited from John and Srivastava (1999). In this research, job performance is evaluated based on the self-assessment of the sales employees in machinery industry with the scale of Behrman and Perreault (1982). With 218 respondents, the model scales are tested for reliability through Cronbach's Alpha coefficient and Exploratory Factor Analysis (EFA). The research results show that the scale of personality trait and job performance has no significant changes.

From the above results, this research has achieved the following objectives:

Firstly, the study has identified five personality trait factors affecting the job performance of salesperson in the machinery industry in Vietnam - openness to experience, conscientiousness, extraversion, agreeableness, and neuroticism.

Secondly, the study measured the influence of personality trait factors on the job performance of salesperson in the machinery industry in Vietnam, in which only neuroticism has the negative effect.

\subsection{Managerial Implications}

Job performance is influenced by personality traits have been accepted by many researchers, but they arrived at different conclusions. This difference is due to different research subjects. For different subjects, personality trait characteristics will be different and that is suitable for different occupations, respectively. This research result once again confirms this difference. And many people apply to this job as a career by choice; each occupation is suited to certain personality traits, which changes very little during adulthood. Research also shows that personality traits always have strengths and weaknesses. The educational environment should create conditions for learners to develop their character in a natural way.

From that, this study proposes some solutions for people who work in human resource management and employees 
who are working in the field of machinery and equipment industry or intend to participate in it.

\subsubsection{For Human Resource Managers in Machinery Industry}

This research shows that, in order to contribute to recruiting suitable personnel for each position, they need to pay attention to the personality traits of the candidate when recruiting. Administrators need a personality trait test to learn about the candidate's personality, from which there are appropriate options as well as solutions to help them develop their job and improve job performance.

A work environment should be created that is open, friendly and comfortable at the company. Then, the salesperson will feel appropriate and is encouraged to be creative and come up with new ideas. Besides, it is necessary to provide rules and working regulations in order to create a disciplined working environment with appropriate and specific promotion policies. That helps sales staff work conscientiously and with purpose, with high responsibility, perseverance, striving to be perfectionist to achieve high performance at work.

\subsubsection{For Sales Employee in Machinery Industry}

Candidates should take the personality trait test, so that they can understand themselves and have a basis in choosing suitable careers in the future. Next, it is necessary to make a good impression on the employer regarding confidence, calmness, communication with others, teamwork ability, etc. Experienced people in machinery and equipment industry also need to regularly attend the company's training courses, develop and train personality trait, thus develop yourself and work more effectively.

\section{References}

Abdullah, I., Rashid, Y., \& Omar, R. (2013), Effect of Personality on Job Performance of Employees: Empirical Evidence from Banking Sector of Pakistan. Middle-East Journal of Scientific Research, 17(12), 1735-1741. doi:10.5829/idosi. mejsr.2013.17.12.1552.

Arndt, A. D., \& Karande, K. (2012). Is it better for salesperson to have the highest customer orientation or a strong fit with their group's customer orientation? Findings from automobile dealerships. Journal of Retailing and Consumer Services, 19(3), 353-359. doi:10.1016/j.jretconser.2012.03.009

Barrick, M. R., \& Mount, M. K. (1991). The big five personality dimensions and job performance: a meta-analysis. Personnel Psychology, 44(1), 1-26.

Barrick, M., \& Ryan, A. M. (Eds.). (2004). Personality and work: Reconsidering the role of personality in organizations (Vol. 20). New York, NY: John Wiley \& Sons.
Barrick, M. R., Mount, M. K., \& Strauss, J. P. (1993). Conscientiousness and performance of sales representatives: Test of the mediating effects of goal setting. Journal of Applied Psychology, 78(5), 715-722. https://doi.org/10.1037/00219010.78.5.715

Basir, M. S., Ahmad, S. Z., Kitchen, P. J., \& Kingdom, U. (2010). The Relationship Between Sales Skills and Salesperson Performance: An Empirical Study in the Malaysia Telecommunications Company. International Journal of Management and Marketing Research, 3(1), 51-74.

Behrman, D. N., \& Perreault Jr, W. D. (1982). Measuring the performance of industrial salespersons. Journal of Business Research, 10(3), 355-370.

Boles, J., Brashear, T., Bellenger, D., \& Barksdale, H. (2000), Relationship selling behaviors: antecedents and relationship with performance. Journal of Business \& Industrial Marketing, 15(2/3), 141-153. doi:10.1108/08858620010316840.

Bradberry, T. (2007). The personality code: Unlock the secret to understanding your boss, your colleagues, your friends - and yourself. London, UK: Penguin.

Brashear, T. G., Bellenger, D. N., Barksdale, H. C., \& Ingram, T. N. (1997), Salesperson behavior: antecedents and links to performance, Journal of Business \& Industrial Marketing, 12(3), 177-184. doi:10.1108/08858629710188018.

Clark, L. A., \& Watson, D. (1991). Tripartite model of anxiety and depression: psychometric evidence and taxonomic implications. Journal of Abnormal Psychology, 100(3), 316-336. https://doi.org/10.1037/0021-843X.100.3.316

Cross, M. E., Brashear, T. G., Rigdon, E. E., \& Bellenger, D. N. (2007), Customer orientation and salesperson performance, European Journal of Marketing, 41(7/8), 821-835. doi:10.1108/03090560710752410.

Dunn, W. S., Mount, M. K., Barrick, M. R., \& Ones, D. S. (1995). Relative importance of personality and general mental ability in managers' judgments of applicant qualifications. Journal of Applied Psychology, 80(4), 500-509. https://doi. org/10.1037/0021-9010.80.4.500

Furnham, A., Forde, L., \& Ferrari, K. (1999). Personality and work motivation. Personality and Individual Differences, 26(6), 1035-1043.

Furnham, A., \& Fudge, C. (2008). The five factor model of personality and sales performance. Journal of Individual Differences, 29(1), 11-16.

Goldberg, L. R. (1981). Language and individual differences: The search for universals in personality lexicons. In: L. Wheeler (Ed.), Review of personality and social psychology (pp.141165). Beverly Hills, CA: Sage.

Hamilton, E. E. (1988). The facilitation of organizational change: An empirical study of factors predicting change agents' effectiveness. The Journal of Applied Behavioral Science, 24(1), 37-59.

Ha, N. M., \& An, N. T. (2015). Impact of Work-Family Conflict on Job Performance of Nurses Working for Hospitals in Ho 
Chi Minh City. Journal of Science Ho Chi Minh City Open University, 4, 16.

Ha, N. M., \& Nguyen, T. V. H. (2014). The influence of leadership behaviors on employee performance in the context of software companies in Vietnam. Advances in Management and Applied Economics, 4(3), 157.

Nguyen, H. M., Nguyen, C., Ngo, T. T., \& Nguyen, L. V. (2019). The effects of job crafting on work engagement and work performance: A study of Vietnamese commercial banks. Journal of Asian Finance, Economics and Business, 6(2), 189-201. https://doi.org/10.13106/jafeb.2019.vol6.no2.189

Han, J. H. (2020). The Effects of Personality Traits on Subjective Well-being and Behavioral Intention Associated with Serious Leisure Experiences. Journal of Asian Finance, Economics and Business, 7(5), 167-176. https://doi.org/10.13106/jafeb.2020. vol7.no5.167

Herzberg, F. (2017). Motivation to work. London, UK: Routledge.

Hough, L. M., Eaton, N. K., Dunnette, M. D., Kamp, J. D., \& McCloy, R. A. (1990). Criterion-related validities of personality constructs and the effect of response distortion on those validities. Journal of Applied Psychology, 75(5), 581-595. https://doi.org/10.1037/0021-9010.75.5.581

Hurtz, G. M., \& Donovan, J. J. (2000). Personality and job performance: The Big Five revisited. Journal of Applied Psychology, 85(6), 869-879. https://doi.org/10.1037/00219010.85.6.869

Jamal, M. (1984). Job stress and job performance controversy: An empirical assessment. Organizational Behavior and Human Performance, 33(1), 1-21.

John, O. P., \& Srivastava, S. (1999). The Big Five trait taxonomy: History, measurement, and theoretical perspectives. Handbook of Personality: Theory and Research, 2(1999), 102-138.

Johnson, J. A. (1997). Units of analysis for the description and explanation of personality. In: R. Hogan, J. A. Johnson, \& S. R. Briggs (Eds.), Handbook of Personality Psychology (pp. 7393). Cambridge, MA: Academic Press.

Judge, T. A., Higgins, C. A., Thoresen, C. J., \& Barrick, M. R. (1999). The big five personality traits, general mental ability, and career success across the life span. Personnel Psychology, 52(3), 621-652.

Judge, T. A., Bono, J. E., Ilies, R., \& Gerhardt, M. W. (2002). Personality and leadership: a qualitative and quantitative review. Journal of Applied Psychology, 87(4), 765-780. https:// doi.org/10.1037/0021-9010.87.4.765

Klang, A. (2012). The Relationship between Personality and Job Performance in Sales: A Replication of Past Research and an Extension to a Swedish Context. Masters' thesis, Stockholm, Sweden: Stockholm University.

Kumar, K., \& Bakhshi, A. (2010). The Five-Factor Model of Personality and Organizational Commitment: Is There Any Relationship? Humanity and Social Sciences Journal, 5(1), 25-34.
Lindner, J. R. (1998). Understanding employee motivation. Journal of Extension, 36(3), 1-8.

Loveland, J. M., Lounsbury, J. W., Park, S. H., \& Jackson, D. W. (2015). Are salesperson born or made? Biology, personality, and the career satisfaction of salesperson. Journal of Business \& Industrial Marketing, 30(2), 233-240. DOI: 10.1108/JBIM12-2012-0257

Matzler, K., Renzl, B., Mooradian, T., von Krogh, G., \& Mueller, J. (2011). Personality traits, affective commitment, documentation of knowledge, and knowledge sharing. The International Journal of Human Resource Management, 22(2), 296-310.

McCrae, R. R., \& Costa, P. T. (1987), Validation of the five-factor model of personality across instruments and observers, Journal of Personality and Social Psychology, 52, 81-90.

McCrae, R. R., \& Costa Jr, P. T. (2004). A contemplated revision of the NEO Five-Factor Inventory. Personality and Individual Differences, 36(3), 587-596.

Nguyen, H. M., Mai, L. T., \& Huynh, T. L. (2019). The role of transformational leadership toward work performance through intrinsic motivation: A study in the Pharmaceutical field in Vietnam. Journal of Asian Finance, Economics and Business, 6(4), 201-212. https://doi.org/10.13106/jafeb.2019.vol6. no4.201

Raudsepp, E. (1990). Are you flexible enough to succeed? Management, 41(4), 6-10.

Rothmann, S., \& Coetzer, E. P. (2003). The big five personality dimensions and job performance. SA Journal of Industrial Psychology, 29(1), 68-74.

Salgado, J. F. (1997). The five factor model of personality and job performance in the European community. Journal of Applied Psychology, 82(1), 30-43. https://doi.org/10.1037/00219010.82.1.30

Smith, J. G., \& Tennessee, M. (2010). Summary Brief A Comparison of the Relationships of a Market Orientation, Agreeableness, Openness to Experience, Gratitude, and Forgiveness to a Salesperson's Customer Orientation. In: Society for Marketing Advances Proceedings (pp. 218-220).

Smithikrai, C. (2007). Personality Traits and Job Success: An investigation in a Thai sample. International Journal of Selection and Assessment, 15(1), 134-138.

Stewart, G. L., \& Nandkeolyar, A. K. (2006). Adaptation and intraindividual variation in sales outcomes: Exploring the interactive effects of personality and environmental opportunity. Personnel Psychology, 59(2), 307-332.

Suliman, A. M. (2001). Work performance: is it one thing or many things? The multidimensionality of performance in a Middle Eastern context. International Journal of Human Resource Management, 12(6), 1049-1061.

Tett, R. P., Jackson, D. N., \& Rothstein, M. (1991). Personality measures as predictors of job performance: A meta-analytic review. Personnel Psychology, 44(4), 703-742. 
Tam Luong HUYNH, Ha Minh NGUYEN, Tram Thi Bich KIEU /

Thoresen, C. J., Bradley, J. C., Bliese, P. D., \& Thoresen, J. D. (2004). The big five personality trait and individual job performance growth trajectories in maintenance and transitional job stages. Journal of Applied Psychology, 89(5), 835-853. doi:10.1037/0021-9010.89.5.835

Tran, D. T., Lee, L. Y., Nguyen, P. T., \& Srisittiratkul, W. (2020). How Leader Characteristics and Leader Member Exchange Lead to Social Capital and Job Performance. Journal of Asian Finance, Economics and Business, 7(1), 269-278. https://doi. org/10.13106/jafeb.2020.vol7.no1.269

van den Berg, P. T., \& Feij, J. A. (2003). Complex relationships among personality traits, job characteristics, and work behaviors. International Journal of Selection and assessment, 11(4), 326-339.

Verbeke, W. (1994), Personality characteristics that predict effective performance of sales people, Scandinavian Journal of Management, 10(1), 49-57. doi:10,1016/0956- 5221(94)90036-1

Vinchur, A. J., Schippmann, J. S., Switzer III, F. S., \& Roth, P. L. (1998). A meta-analytic review of predictors of job performance for salesperson. Journal of Applied Psychology, 83(4), 586-597. https://doi.org/10.1037/0021-9010.83.4.586
Vroom, V. (1964). Work and motivation. New York, NY: John Wiley and Sons.

Wallace, C., \& Chen, G. (2006). A multilevel integration of personality, climate, self-regulation, and performance. Personnel Psychology, 59(3), 529-557.

Wetzels, M., De Ruyter, K., \& Bloemer, J. (2000). Antecedents and consequences of role stress of retail sales persons. Journal of Retailing and Consumer Services, 7(2), 65-75.

Wisker, L. (2011). The impact of personality traits on sales performance: A comparative study between Muslim and non-Muslim managers. Working Paper. Eastern Institute of Technology. New Zealand.

Witt, L. A., Burke, L. A., Barrick, M. R., \& Mount, M. K. (2002). The interactive effects of conscientiousness and agreeableness on job performance. Journal of Applied Psychology, 87(1), 164-169. https://doi.org/10.1037/0021-9010.87.1.164

Yurtkorub, S. (2013). Job stress and job performance among employees in public sector in Istanbul: examining the moderating role of emotional intelligence. Procedia-Social and Behavioral Sciences, 75, 518-524. 